\title{
'Escapando de la clase tradicional': the escape rooms methodology within the spanish as foreign language classroom
}

\author{
Mário Rui Domingues Ferreira da Cruz
}

\begin{abstract}
The escape games or the so-called escape rooms industry is booming nowadays. Due to the fact that this type of live-action team-based games (Nicholson, 2016) require a great deal of communication and critical thinking, it is quite easy to think of its application at education. This paper aims at discussing on how to use escape room concepts for educational purposes and, more specifically, in Spanish as Foreign Language (SFL) classroom. Moreover, it is also our aim to present a case study in which students were invited to both create and participate in an escape room. Therefore, we will be focusing on escape room design applied to the teaching of SFL setting, taking into consideration game narratives, puzzle types and rooms organisation aspects. By following an ethnographic methodological approach, a case study was undertaken in which the following data-collection tools were used: a) questionnaires to figure out students' perceptions on escape rooms and on the influence of escape room methodologies onto the development of skills; b) field notes, pictures and videos collected during the application of the escape room activities. The main results show that students considered both escape rooms catered for the development of 21 st century skills.
\end{abstract}

Keywords:

escape room methodology; gamification; spanish as foreign language 


\title{
'Escapando de la clase tradicional': a metodologia das "Escape Rooms" na sala de aula de Espanhol como Língua Estrangeira
}

\begin{abstract}
Resumo: As Escape Rooms ou a indústria de "Escape Rooms" estão a crescer a um ritmo alucinante hoje em dia. Devido ao facto de este tipo de jogo colaborativo de ação ao vivo (Nicholson, 2016) exigir muita comunicação e pensamento crítico, é bastante fácil pensar na sua aplicabilidade em contextos educativos. Este artigo tem como objetivo discutir como usar o conceito de "Escape Room" com fins educativos e, mais especificamente, na aula de Espanhol como Língua Estrangeira (ELE). Além disso, também é nosso objetivo apresentar um estudo de caso no qual os alunos foram convidados a criar e participar em "Escape Rooms". Portanto, prestaremos atenção ao design de "Escape Rooms" aplicado ao ensino de ELE, tendo em conta as narrativas do jogo, os tipos de quebra-cabeças e os aspetos da organização das salas. Seguindo uma abordagem metodológica etnográfica, foi realizado um estudo de caso no qual foram utilizadas as seguintes ferramentas de recolha de dados: a) questionários para inventariar as percepções dos alunos sobre as "Escape Rooms" e a influência das metodologias desta natureza no desenvolvimento de competências; b) notas de campo, fotos e vídeos recolhidos durante a aplicação das atividades de "Escape Room". Os principais resultados mostram que os estudantes consideraram que as duas "Escape Rooms" promoveram o desenvolvimento de competências do século XXI.
\end{abstract}

Palavras-chave: metodologia "Escape Room"; gamificação; espanhol como língua estrangeira

\section{'Escapando de la clase tradicional': la metodología de las salas de escape en el aula de Español como Lengua Extranjera}

Resumen: Los juegos de escape o la llamada industria de salas de escape está en auge hoy en día. Debido al hecho de que este tipo de juegos basados en equipos de acción en vivo (Nicholson, 2016) requieren una gran cantidad de comunicación y pensamiento crítico, es bastante fácil pensar en su aplicación educativa. Este documento tiene como objetivo discutir sobre cómo usar los conceptos de la sala de escape con fines educativos y, más específicamente, en el aula de español como lengua extranjera (ELE). Además, nuestro objetivo es presentar un estudio de caso en el que los estudiantes fueron invitados a crear y participar en una sala de escape. Por lo tanto, nos centraremos en el diseño de la sala de escape aplicado a la sala de ELE, teniendo en cuenta las narrativas de los juegos, los tipos de rompecabezas y la organización de las salas. Siguiendo un enfoque metodológico etnográfico, se realizó un estudio de caso en el que se utilizaron las siguientes herramientas de recopilación de datos: a) cuestionarios para determinar las percepciones de los estudiantes sobre las salas de escape y sobre la influencia de las metodologías de la sala de escape en el desarrollo de destrezas; b) notas de campo, fotos y videos recopilados durante la aplicación de las actividades de la sala de escape. Los principales resultados muestran que los estudiantes consideraron que ambas salas de escape atendían el desarrollo de habilidades del siglo XXI.

Palabras-clave: metodología de sala de escape; gamificación; español como lengua extranjera

\section{'Escapando de la clase tradicional': la méthodologie de les jeux d'evesion dans la clase d'espagnol comme langue étrangère}

Resumé: Les jeux d'évasion ou ce qu'on appelle l'industrie des salles d'évasion est en plein essor aujourd'hui. Étant donné que ce type de jeux basé sur des équipes d'action réelle (Nicholson, 2016) nécessite beaucoup de communication et de réflexion critique, il est assez facile de penser à leur application pédagogique. L'article a pour objectif de discuter l'utilisation des concepts de la salle d'évasion à des fins pédagogiques et, plus précisément, dans la salle de classe de l'espagnol comme langue étrangère (ELE). En outre, notre objectif est de présenter une étude de cas dans laquelle les étudiants ont été invités à créer et à participer à une salle d'évasion. Par conséquent, nous allons nous concentrer sur la conception de la salle d'échappement appliquée à la salle ELE, en tenant compte des récits des jeux, des types de puzzles et de l'organisation des salles. Suivant une approche méthodologique ethnographique, une étude de cas a été réalisée dans laquelle les outils de collecte de données suivants ont été utilisés: a) des questionnaires permettant de déterminer les perceptions des étudiants concernant les salles d'évasion "Escape Room" et l'influence de leurs méthodologies contribuent au développement des compétences; b) des notes de terrain, des photos et des vidéos collectées lors de l'application des activités de la salle d'évasion. Les principaux résultats montrent que les étudiants ont estimé que les deux salles d"Escape Room" contribuent au développement des compétences du XXle siècle.

Mots-clés: méthodologie de la salle d'événement; gamification; l'espagnol comme langue étrangère. 


\section{Introduction}

Nowadays students must be provoked by undertaking activities which allow them to learn essential skills for their success in our local society, as these cater for a new view of the world. Within this scope, we would like to highlight the importance of communication, critical thinking and collaboration, as far as languages learning is concerned, as it is the case of our study.

Bearing in mind that languages learning may help to contribute towards the development of future citizens, we should (re)think our practices in order to achieve a teaching and learning process which integrate activities that simulate students' present-day life and its routines, and at the same time cater for the fostering of a pro-active citizen who is able to undertake an active role in his/her glocal society.

In this article we will reflect, on the one hand, on the new skills needed for the $21 \mathrm{st}$ century work contexts and the resulting challenging changes in teaching and learning practices within foreign languages learning, by including new methodologies and strategies, especially the ones which resemble technology and gamified contexts, as the "Escape Room" methodology.

\section{1st Century Skills within SFL Learning}

At present days we are living in a new era in education in colleges and universities, an era in which students contact with different sources of information, ranging from the television to the Internet and its applications, and at the same time languages and cultures.

In fact, on the one hand, we all know that development of communicative skills also depend on the kind of exposure students have in their real-life activities; on the other hand, we need to adjust our practices to satisfy their linguistic and cultural needs, by incorporating methodologies and strategies which replicate most real and present-day activities.

According to the P21 (2015), a coalition, created by teachers, employers, education stakeholders and politicians from all over the world, students need the proper opportunities and paths to gain life-skills for their future jobs. This coalition listed the competency basis which they considered to be crucial for success in every workplace. The list can be divided into three main core skills, namely:

a. Learning and innovation skills, from which creative thinking, collaboration, communication, critical thinking and problem solving make part;

b. Information, Media and Technology Skills, which can be considered as the tools that students need to master in order to work in both digital and non-digital contexts; 
c. Life and career skills, which are considered to be the habits, routines and mindsets which should be fostered, so that students can accept feedback as a positive thing, are able to work in teams, may adapt to change and even see the bright side of competition.

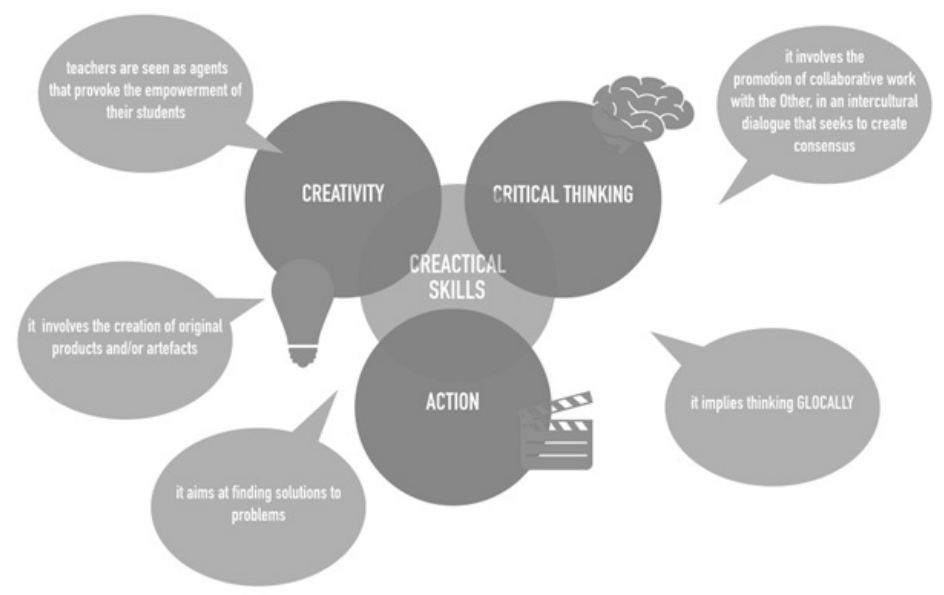

Figure 1 - The "Creactical Skills" (Cruz, 2019; Ohler, 2013)

In this context, we believe that foreign languages learning is more than getting to know grammar rules and how to avoid mistakes in communication (cf. Bérard, 1991). It implies a focus on the development of sociocultural skills, having into account students' motivation and the training of "creactical skills" (Figure 1), critical thinking and creativity into action (cf. Cruz, 2019; Ohler, 2013). In fact, in our present-day world, foreign languages teaching must be intrinsically connected with the social, economic, political and cultural contexts, especially if we consider the case of Spanish language due to its ascending importance within the global scenario (Cruz \& Saracho, 2018).

Let us now reflect upon how we should enhance Spanish language teaching by focusing on new approaches and methodologies, namely the experiential communicative approach and the didactics of gamification.

\section{The Experiential Communicative Approach and the Didactics of Gamification within Languages Learning}

As we have seen in the previous section, the teacher is expected to develop a teaching and learning process based on daily life tasks, by undertaking a reformulation of the pedagogical scenario. Therefore, the development of students' competences should be encouraged, hoping that they will be trained to be responsible for their 
learning, as individuals who are capable of actively (re)build knowledge based on reflection and collaborative practices.

This can be achieved through the experiential communicative approach, which invites students to develop their interests and motivational needs in exploring society they make part of, always in interaction with the Other. In this context, creativity, flexibility, the need to take risks and assume leadership characterise this approach to learning (cf. Cruz \& Orange, 2016). Multi-sensory practices can respond to effective student needs based on experience and fostering multimodal learning. By transforming the senses into perception channels which activate brain connections (Shams \& Seitz, 2008), this type of learning offers students the possibility of developing their knowledge through experience (Figure 2). In other words, taking into account Spanish language learning, students should have the opportunity to cook "gallo pinto" or to smell a freshly made taco, as well as learn the dance routines of salsa, instead of simply reading about these objects or activities (cf. Cruz, 2018).

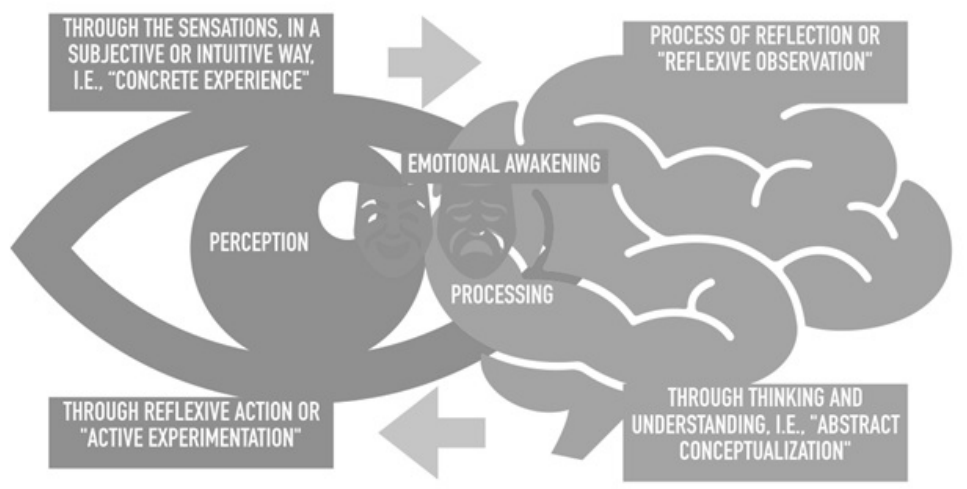

Figure 2 - The Experiential Communicative Approach Model

As stated by Cruz (2018, p. 320), multi-sensorial environments allow "students to have the opportunity to develop reflective paths that stimulate their critical analysis of the experiences they have gone through, while enriching their Weltwissen with proactive knowledge, which allows them to recreate similar paths in other contexts (...)".

Within the scope of the experiential communicative approach students are individuals with past experiences and real expectations. For this reason, we should engage our students by integrating the affective dimension in our practices, by connecting each task we propose with their own previous experiences and the world of sensations.

Likewise, the gamification pedagogy can be linked to the experiential communicative approach. In fact, when creating an experiential didactic task, we must design a learning activity by "introducing elements of the game (badges, time limit, scores, dice, etc.) and 
their thinking (challenges, competition, etc.)" (Foncubierta \& Rodríguez, 2015, p. 2). Also as Kapp (2012) refers, gamification is nothing more than the use of game elements, such as its mechanics, motivation and problem-solving features, in the creation of didactic activities, in order to make them more attractive in the eyes of our students.

The main aim of a gamified activity is to give students the opportunity to be encouraged, immersed and involved in environments that are known. The use of dynamics, mechanics and components of the game contributes to a state of continuous flow at the time of learning, i.e., an intrinsic motivation. Behind the gamification pedagogy assumptions, one can find the self-determination theory (cf. Werbach \& Hunter, 2012), which is related to the inherent growth tendencies and the innate psychological needs of people, being concerned with the motivation behind the choices that people make without external influence and interference.

The creation of gamified tasks can be undertaken under Chou's Octalysis model (2016) and its eight key impulses: the epic calling, empowerment, social influence, unpredictability, scarcity, avoidance, belonging and achievement (Figure 3).

This model uses as its frame of reference an octagon, which contains 8 units or key impulses, namely: 1) "meaning" (when a person believes that he/she was "chosen" to perform that action); 2) "empowerment" (it involves a creative process); 3) "social influence and relationship" (it involves learning, social acceptance, companionship, and even competitiveness); 4) unpredictability (something is done because you do not know what is going to happen next); 5) "avoidance" (it implies prevent from losing a round, not falling behind, etc.); 6) "scarcity" (when one wants something simply because it is extremely rare); 7) "ownership" (when one feels that own something or control it); 8) "achievement" (it is related to the collection of points, badges, etc.).

According to Yu-Kai Chou (2016), when preparing didactic activities, these core drives must be taken into account in order to "hook" or motivate the students. If there is none of these units, there will be no motivation, and subsequently no action or no change in students' behaviour towards learning itself.

As we are going to figure out within the next chapter, escape rooms include all these core drives, being a true gamified experience for students. 


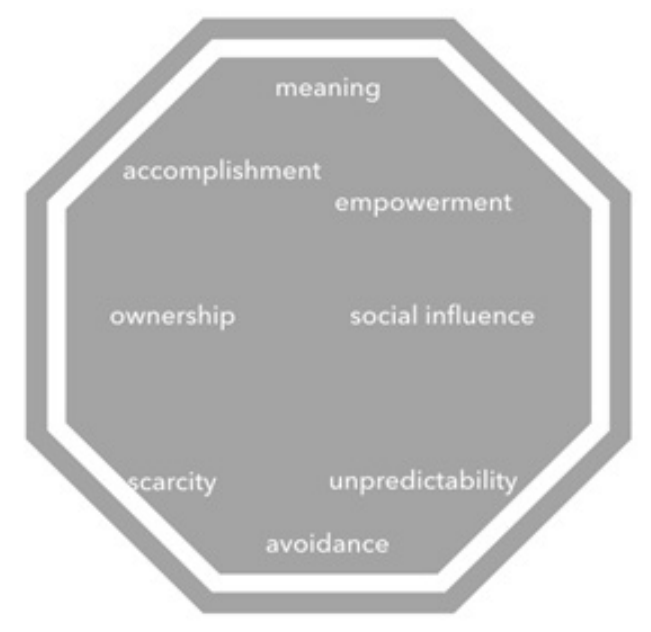

Figure 3 - The Octalysis Framework Model

\section{From the Escape Room Industry to Educational Escape Rooms}

The escape rooms are action games that unfold in a real context, where groups of people or teams must uncover clues and undertake challenges to solve a particular mystery or "escape" a given space, taking into account that the time is limited. As Nicholson (2016, p. 1) indicates, escape rooms work as "live-action team-based games where players discover clues, solve puzzles, and accomplish tasks in one or more rooms in order to accomplish a specific goal. usually escaping from the room) in a limited amount of time."

Usually, an escape room takes place in a room where groups of students, teams which include from 3 up to 8 students, have the chance to explore. However, experience shall begin outside this space, by giving them instructions in order to participate according to the rules and explain the story behind the whole mystery. From the moment they enter the room, participants have to explore the environment in order to discover clues, objects, puzzles and any other type of details that allow them to solve the problems, challenges and, ultimately, the mystery (Nicholson, 2015, WEB).

Due to the fact that these activities require teamwork and the development of communication practices and critical thinking, we easily consider its application in educational contexts, especially if we take into account the importance that didactics of gamification has been gaining in the last decade, which can be accounted for the quantity and quality of educational studies that have been published (cf. Guigon, 2018). 
Particularly collaborative in its essence, this type of games invites its participants to use all their psychosocial skills in order to foster learning, so that through teamwork and permanent adaptation to the context and challenges they are able to "escape" from the room. In fact, participants in an escape room have the chance to develop in real time: a) cognitive skills, such as logic, memorisation, attention, deductive thinking, creativity, problem solving, time management and resources; b) social skills of teamwork, cooperation, including leadership; c) psychological skills, such as the expression of emotions, the management of feelings associated with gain or loss and self-knowledge (Burgos Berzosa, 2018).

The creation of escape rooms for educational purposes is something relatively new. However, present studies show that these are gamified proposals that quite offer another perspective on the role of the game within the teaching-learning process.

\section{The design of "Escape Rooms" for SFL learning}

The creation of an educational escape room must be done with the responsibility and rigor inherent to the preparation of any didactic activity. It is recommended that teachers have into account specific factors while designing an escape room, namely: a) to prepare it in a meaningful way for the students to whom it is addressed; c) to bear in mind that the creation of an escape room is done in a progressive way, so it is necessary to design, test and redesign it.

According to Guigon (2018), during the design process of an escape room, one must take the following aspects into account: 1) the narrative; 2) the types of puzzles; 3) the organisation of space and the contribution to the puzzles flow. Let us now focus our attention on each of these aspects we took into account in the creation of the escape rooms we are going to present later within this article.

Regarding the first aspect, the creation of context and story that justifies all the challenges students will go through. It should be as immersive as possible. This immersion in the story itself is achieved and lived through the creation of a context, in which the aesthetic decoration and the puzzles flow feedback the whole experience. In a study related to escape rooms, Nicholson (2015) discusses the most frequent themes and narratives, which we sum up in Table 1. 
Table 1 - Frequent themes and narratives in escape room games

\begin{tabular}{|l|l|}
\hline Most recurring themes & Most recurring narratives \\
\hline - Cartoons & $\begin{array}{c}\text { - Help create something (a cure, an antidote, a } \\
\text { potion, etc.) } \\
\text { - School }\end{array}$ \\
- Fantasy & - Disable an explosive device \\
- Laboratory & $\begin{array}{l}\text { Escape from some spaces (prison, dungeon, place } \\
\text { ready to explode, etc.) }\end{array}$ \\
- Linked to a given time or time (current time or a & - Investigate a crime (murder or robbery, for \\
- Future technology & $\begin{array}{l}\text { example) } \\
\text { - Linked to seasons or festive themes of the year }\end{array}$ \\
(Summer, Christmas, Halloween, Easter, etc.) & $\begin{array}{l}\text { disappeared } \\
\text { - Military }\end{array}$ \\
- Horror (Zombies, Vampires, etc.) & \\
\hline
\end{tabular}

Source: adapted from (Nicholson, 2015)

As far as puzzle types are concerned, one must take into consideration that experience has its own rules, and this must be made clear to players. At the same time, we must share with the players information related to the narrative, through an introductory video or a live character, who can be found inside the room, too.

During the experience in the room, players will encounter various objects that they will have to manipulate in a logical way, in order to fulfil the goal in a fixed time. The most common puzzles used in educational escape rooms are:

a. the search for hidden physical objects, including those that are unusual (paper in the trash bin, a postcard or envelope, a message on the wall, a padlock and a key, a mirror to read a message that is deciphered when reflected, boxes, photos, posters, USB pens, QR codes, books, keys, etc.), and the discovery of their use;

b. the analysis of information in a text which allows that specific text parts help to contribute to the narrative progression (including the selection of certain letters or words, through a perforated card whose holes identify what it is essential or even access a certain message that can only be read with ultraviolet flashlight);

c. the use of codes without a physical key, in which by combining letters and numbers, players can discover object names or a hint;

d. puzzles or riddles that present themselves as problems which use metaphorical or allegorical language, and which usually allow access to objects or codes that make players go forward in solving the mystery; 
e. traditional crosswords, which can be easily generated through puzzle generators present on the internet and in which a word stands out as a clue (cf. Burgos Berzosa, 2018; Guigon, 2018).

Finally, the organisation of the puzzles and their flow are also particularly important. It can be: a) open, in which they do not depend on a specific sequence; b) sequential, in which one puzzle leads successively to another, by following the clues that each one contains; c) trajectory, in which there are several paths and possibilities that contribute to the resolution of the objective, being this one the most used and recommended for large groups (cf. Burgos Berzosa, 2018).

\section{5. 'Escapando de la clase tradicional' project: a case study}

In this section we will present our 'Escapando de la clase tradicional' ('Escaping from traditional classroom') project.

\subsection{Research methodology: its context, research questions and collection tools}

This project has been undertaken at the School of Education of the Polytechnic of Oporto with two groups of students, who are attending either Spanish A2 or Spanish B1.2 classes. The majority of students is between 17 and 25 years old (94\%) and are female (70\%). All of them are Portuguese citizens and have Portuguese as their native language. There are four other students who have also got French and German as second languages.

Our research questions are the following: 1) Which perceptions do students have of escape rooms and its use in educational contexts?; 2) Which skills students have the chance to develop when participating both in the implementation and creation of educational escape rooms?; 3) Which sort of escape room design and strategies are more appropriate for educational purposes, especially in foreign languages teaching settings, namely the SFL classroom?

By following an ethnographic methodological approach, a case study was undertaken in which the following data-collection tools were used: a) a pre-questionnaire to figure out students' opinion and experience on escape rooms; b) a final questionnaire to get to know their opinion on the influence of escape room methodologies onto the development of skills; c) field notes, pictures and videos were collected during the application of the escape room activities.

Within this case study, students were able to both participate and create escape rooms by following the experiential communicative approach enhanced by hyper pedagogy strategies. Therefore, two educational escape rooms were created, having into account Two Spanish TV series, namely 'Money Heist' ('La casa de papel') and 'Elite' (Élite). Within the first escape room, students had to discover who was the thief behind 
a microwave's robbery, by solving a series of puzzles related to the revision of some topics, including vocabulary (clothes, trips, environment, mass media), verb tenses, linking words, etc. The second escape room was created by the Spanish B1.2 level students in order to be implemented within Spanish A2 level classes. These students had to unveil who was the one who murdered one of their mate students, by following a couple of leads and solving puzzles and tasks related to the "love and friendship" unit, in which students have to learn vocabulary related to the topic, verb tenses, etc.

\subsection{Analysis of students' perceptions on escape rooms as a methodology for educational settings}

Focusing on the questionnaires, which were fulfilled before the implementation of the escape room, 38 students had the chance to share their perceptions. Most students know what an escape room is (72\%), having described it as the following: "It is a kind of game in which we have to solve several challenges to finally find out where the key is that will allow us to leave the escape room and win" (S1). However, none of the students have had the chance to participate in a real escape room.

As we can observe in Graph 1, most students think that the escape room methodology is applicable to learning settings and feel that this kind of methodology fosters collaborative work, allows for the development of critical thinking and communication skills. However, they are not motivated by winning feelings and not all of them see themselves designing an escape room.

Graph 1 - Students' perceptions on escape rooms as a methodology for educational purposes

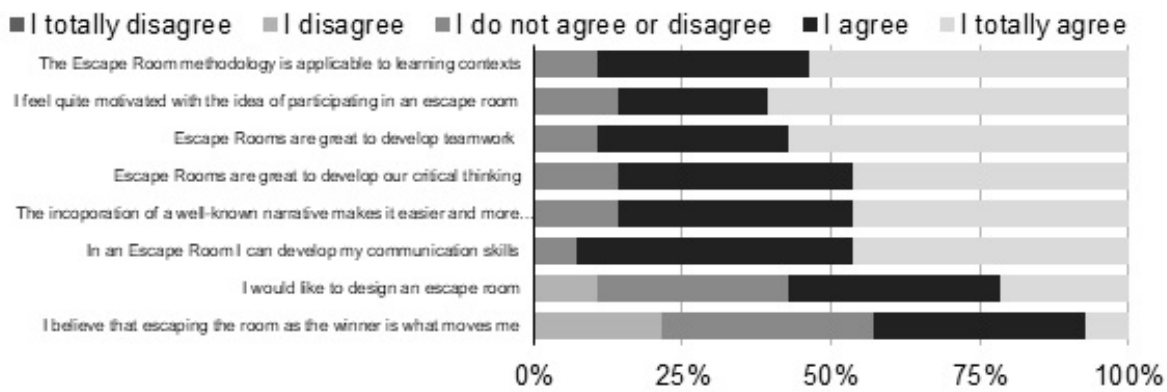

When asked about the narratives of an educational Escape Room, most students suggest they would like to have settings that resemble popular films or TV series, such as: 'Hunger Games', 'Game of Thrones', 'Money Heist', 'Elite', 'Orange is the new black" etc. Others go a little bit further and explain how the Escape Room should work, as for example the following one we selected to illustrate their opinions: "An interesting 
escape room, in my opinion, would be an escape room where we could forget the grammatical part and focus on the cultural part (...)" (S4).

Bearing in mind these perceptions and views, the teacher conceived an escape room and asked the same students who participated in this one to conceive and design another escape room for their colleagues who were attending Spanish A2 classes. Let us now analyse these two escape rooms proposals, including students' own views about them.

5.3. 'El robo de los microondas' ('The Microwaves Robbery'): design of an 'Escape Room' based on 'Money Heist' TV series by the teacher

The first escape room, which we are going to analyse, was created by the teacher and implemented within the Spanish B1.2 classes. It worked out as a revision activity which was undertaken in the end of the semester.

Focusing on its design, this escape room's narrative was created having into account 'Money Heist', which is one of the TV series that interests students the most, but at the same time we tried to incorporate one of the topics related to their college life, in order to make the experience more attractive and memorable (cf. Guigon, 2018). In fact, students had to collect money to buy their own microwaves. Therefore, students quite value the existence of these devices at the college premises due to the fact they had to invest their own money on buying three microwaves.

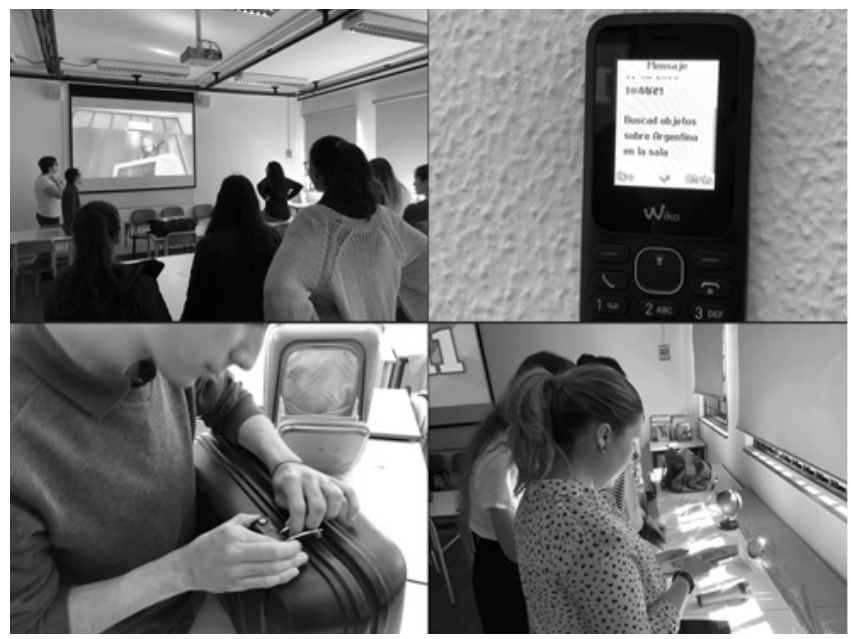

Figure 4 - Glimpse of the aesthetic decoration and puzzles within the Escape Room 
This immersion of students in the story itself was achieved and lived through the creation of the context, in which the introductory video and the aesthetic decoration played a very important role, including two mobile phones which hung on the wall (as in the TV series) and acted as helpers through some of the tasks (Figure 4).

Taking the puzzles into consideration, students were enticed before participating in the escape room through WhatsApp messages, according to which they had to figure out the number of the classroom the escape room would take place:

Somos muy pequeños, como
ratones que tienen que ir por la vida
haciendo agujeros, porque no
tenemos ni idea de otra cosa para
hacer.
El Martes harás otra cosa más...
\[ \text { seg, 10/06 } \]
¿Descubrirás dónde tienes que
jugar mañana?
Te doy dos adivinas... Las primeras
letras de las palabras que
adivinarás son el código
alfanumérico de la sala donde
entrarás...
Llevo dinero y no soy banquero,
papel o metal, lo que sea me da
igual. ¿Qué es?

Figure 5 - WhatsApp messages sent by the teacher to the students in order to create anticipation

Focusing on the puzzles flow, we followed a sequential approach, in which students would unveil the mystery by moving from task to task (cf. Burgos Berzosa, 2018). During the experience, our students had the chance to encounter diverse objects which they had to manipulate in order to fulfil the goal in the end, i.e., finding out who stole the microwaves. The puzzles they encountered were the following:

1) a message written backwards which could only be unveiled by reflecting it on a mirror (https://app.box.com/s/vaulewupuyzl5lyyqor2vv0wlsgh0qv6); 
2) a crossword puzzle (Figure 6) which could be found in the trash bin, and once solved a perforated cardboard could be used in order to find out the hidden letters $G$ - L - O - B - O;

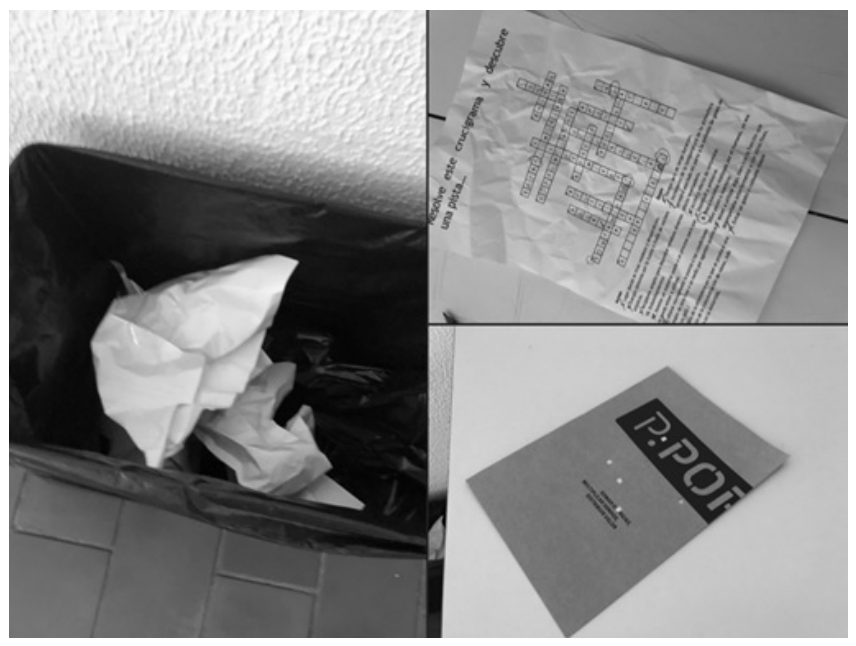

Figure 6 - Crossword Puzzle (https://app.box.com/s/l9147gdk3z5yn3c0lxpbjvq3wibf5zxx)

3) a globe with a hidden key, which would let them open a trolley bag which had another task;

4) a message with some exercises on subjunctive verbs which if properly solved would unveil the code to open the safe (https://app.box.com/s/zvhd5qctuw472Isxnskvphi3l7k7fiei);

5) an e-mail message with multiple-choice exercises, in which students had to complete a text in order to obtain an alphanumeric code that would unveil the country the microwave thief would flee to (https://app.box.com/s/jOlpqdhmmi5csegk2amg6t6x3iakgd5h);

6) a final task with a QR code, which students would have to access in order to watch a video about the city the thief would be fleeing to and solve some filling-in gap exercises that allow them to unveil the numeric code of the thief's luggage in a deck of cards (Figure 7). 


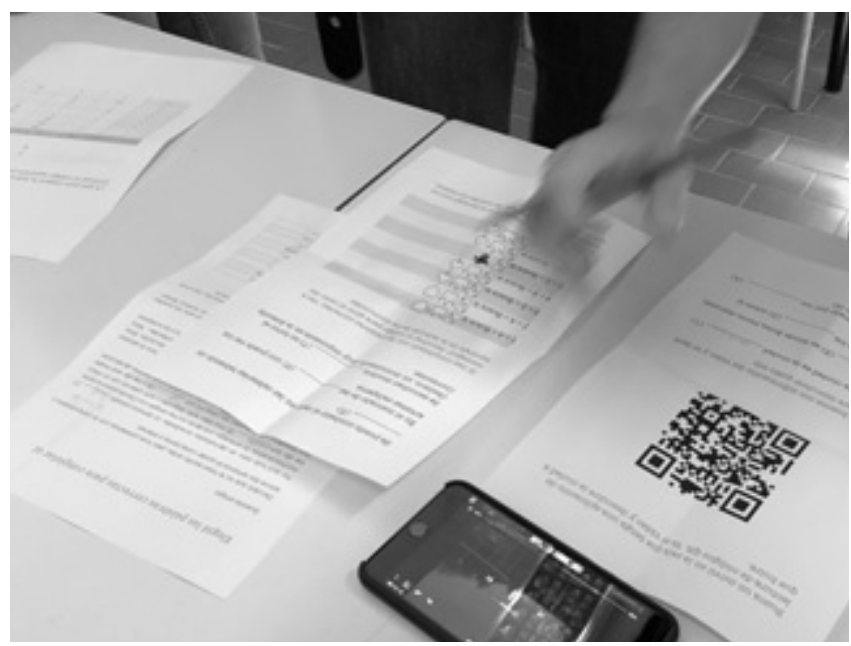

Figure 7 - Students watching the video and solving the exercise (https://app.box.com/s/9t01n7ni8kxju4kvhce0qxdxzzu540gf)

In the end students would find inside the luggage some cards with the letters from the thief's name. Once they ordered them they had to send a WhatsApp message with their answer (https://app.box.com/s/7v3gh54irnpys1mijp1qvhnnplke1ioo) and would be getting a video of the thief, revealing her true identity.

5.4. 'El asesinato de Edgar' ('Edgar's Murder'): design of an 'Escape Room' based on 'Elite' TV series by Spanish B1.2 students

As regards the second escape room, 'El asesinato de Edgar' ('Edgar's Murder'), its design and almost every puzzle were conceived by Spanish B1.2 students during three lessons (90 minutes each). In fact, students had the chance to revise contents while creating the series of puzzles and narrative.

These collaborative sessions were moments which students used to discuss the design of the escape room and its puzzles, that were presented and discussed by each one of the groups involved in the creation of this escape room.

In the end, students conceived a sequential escape room, in which one puzzle leads successively to another (cf. Burgos Berzosa, 2018) and invites students to unveil who was the one who murdered one of their colleagues, by following a couple of leads and solving puzzles related to different cultural and grammar topics (vocabulary and expressions related to "trips and airport", "love and friendship", "world heritage places, etc." and past verb tenses). 
The puzzles they conceived are the following:

1. students were introduced to the escape room narrative through an audio recorded by the School of Education Radio reporter, which can be listened at https://app.box. com/s/i3eu4ilptl3tlc2w81r2rgtddw8yl2tc;

2. an envelope with a map and three questions which deal with the Spanish-speaking countries and cities, whose location would give students a code to open a chest (https://app.box.com/s/d1il4oyf093a5t4a13v6ycm6ykhpyzo2);

3. a chest which entails a QR code with a lady throwing a paper into the trash bin, leading students to look for something in the trash bin itself (https://app.box.com/s/ m9layo5zcj3cgkvr8m1vhlx3socst2hn);

4. a love letter written backwards by the protagonist's love (Figure 8), which could only be unveiled by reflecting it on a mirror and whose signature was written in a numeric code students had to unveil;

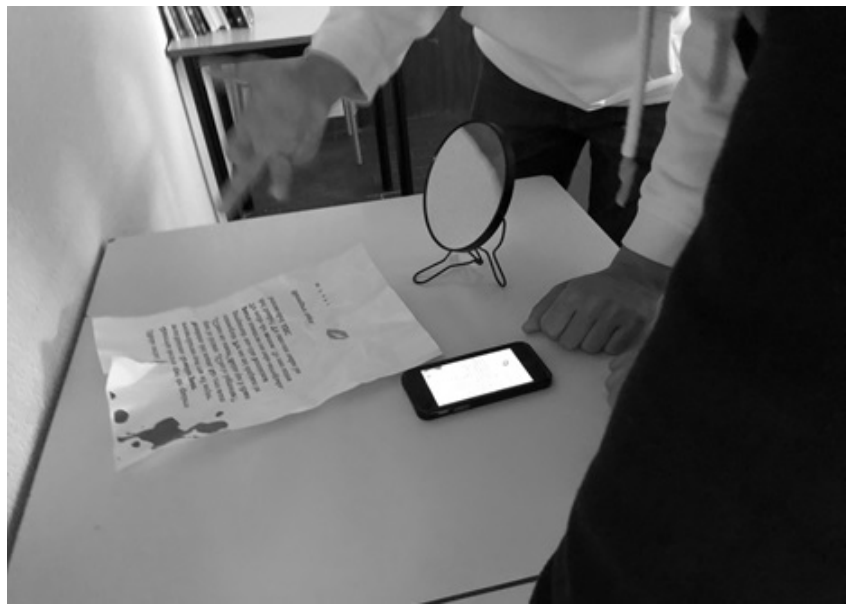

Figure 8 - Students solving the puzzle related to the love letter and the mirror puzzle (https://app.box.com/s/di5daretyfp8e0y6o34ows3quoq8z5fs)

5. a crossword puzzle which could be found in another envelope with had the message "From Nadia to Edgar, with love", and once solved would allow students to discover the word "Literature", inciting them to search for another clue in one of the books present in the room (https://app.box.com/s/txva1a7ofph63uxv9a18k5a5sg51fo8v);

6. a book with a hidden key that would let them open a bag which had another task, an exercise on past verb tenses and words collocation, which would allow students to unveil a numeric code to open Edgar's luggage;

7. within Edgar's luggage, students would get the chance to develop a reading comprehension exercise by having a look at some pages of Edgar's diary (https://app.box. com/s/0kmq0g0pki753pe5u1nuosyx9hyv1ead), through which they would figure out 
that the word "TROFEO" would lead them to discover Edgar's killer by discovering a USB key hidden in the trophy present in the room (Figure 9)

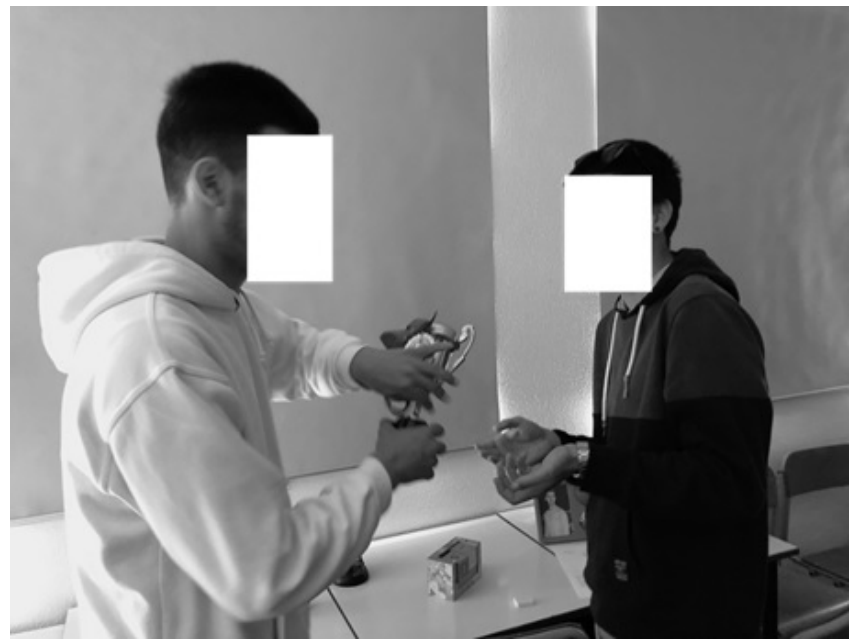

Figure 9 - Students discovering the USB Pen drive

\subsection{Analysis of students' perceptions on both escape rooms and their participation in the design}

Regarding the final questionnaire's results, most students consider that they had the chance to learn in an engaging, interactive and significant way. This can be seen in Graph 2. In fact, if we compare this graph with the results within the preliminary ones (Graph 1), we may observe that a great deal more of the answers is now concentrated within "I agree" and "I totally agree" values. It is now clear to us that most students considered they developed their collaborative, communication and critical thinking skills (only one student disagreed with this).

Graph 2 - Students' representations on the escape room they took place in

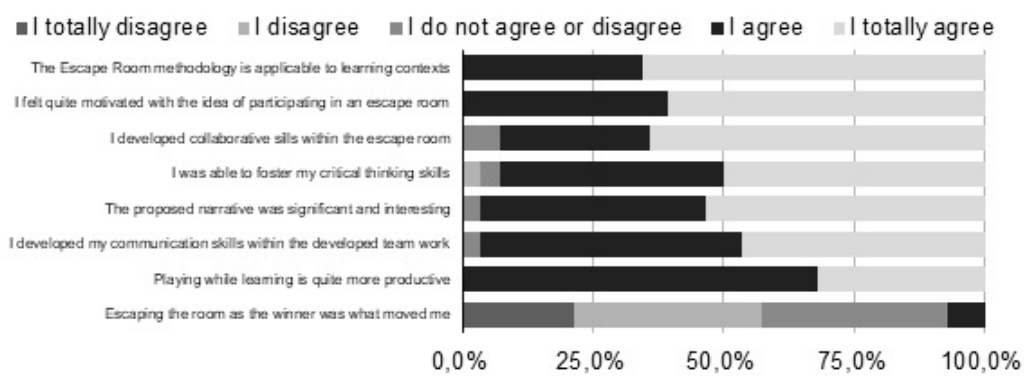


If we ask students to assess the escape room they participated in, taking into account the narrative, types of puzzle, organisation of the room, use of technological resources, role of characters, among other aspects, students shared their views regarding

a) its design

"It was a very educational experience, as the puzzles were very well done and steps were connected" (S2)

b) its narrative

"The narrative was incredible (...), the room had a very good organization and drew attention to the different clues, contained real objects but we were able to resort to more technological resources such as mobile phones" (S3)

c) the learning opportunities it offered

"I think the Escape Room was organized. It helped in thinking, creativity and, in a way, teamwork but in the end we should have access to the different exercises solutions (S8)

d) its organisation and implementation

"I think the escape room had an appealing and funny narrative, and that the games used were appropriate to develop our critical thinking. (...) However, I think the number of people was very large and did not allow us to develop any teamwork" (S10)

Regarding the skills that the students developed within the design of the escape room 'El asesinato de Edgar' ('Edgar's Murder'), the majority of students considered creativity, collaboration, communication and critical thinking skills as the ones which were fostered while creating the tasks (Graph 3).

Graph 3 - Skills that the students developed within the design of the escape room 'El asesinato de Edgar' ('Edgar's Murder')

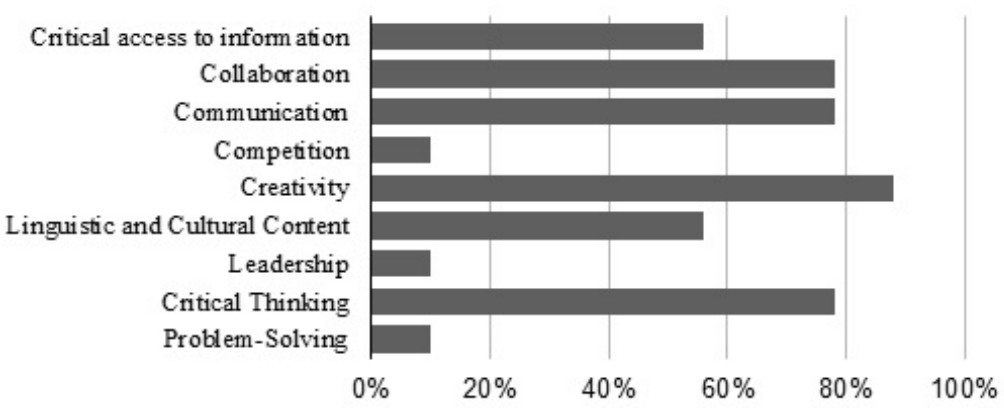

Some students explained in which ways they had the chance to develop these skills, as we can see in the following examples: "Having created the narrative, I feel I developed my critical thinking taking into account the purpose of the game and my 
creativity in inventing a plausible plot. The training in audio editing was necessary" (S12) and "When creating challenges for the escape room I felt that my creativity and problem solving (when we did not get the expected results) were the most developed skills"(S13).

\section{Final Considerations}

In this article we were able to focus on the escape room methodology, its features and design rules, and at the same time to present and analyse a case study in which students were able to reflect critically and solve problems by participating and creating some escape rooms puzzle activities within the SFL classroom.

Regarding our main findings, we would like to refer that: a) students had the chance to interpret, share their own ideas, work together and show compromising within the achievement of team's goals; b) by creating their own escape room, students felt motivated and reflective, being able to manage their goals and time; c) groups bigger than 6 members do not facilitate collaborative practices and narrative immersion; d) collaborative, critical thinking and creativity skills were the main skills students fostered, above all for the students who designed an "Escape Room"; e) all comprehension and expression macro skills were integrated, but a balance between grammar and other types of content and its systematisation should have existed.

\section{Notes}

1 An example can be found here: https://www.education.com/worksheet-generator/reading/crossword-puzzle/.

2 This questionnaire can be accessed here: https://forms.gle/WdPCZY4tLUaNDcXWA.

${ }_{3}$ The final questionnaire can be analysed here: https://forms.gle/wR7oE8fsRqeh7RqE7.

${ }_{4}^{4}$ The video can be found here: https://vimeo.com/user66694393/review/342707300/dbca5d9305.

5 This video can be accessed here: https://vimeo.com/user66694393/review/342713654/ c793ae677a.

6 This student explained later on that the number of students participating did not allow for the development of true group work.

\section{References}

Bérard, E. (1991). L'approche communicative. Théorie et Pratiques. Paris: Clé International.

Burgos Berzosa, J. (2018). Manual de diseño de un Juego de Escape. Retrieved from http:// culturaemprendedora.extremaduraempresarial.es/wp-content/uploads/2018/04/Manual-deEscape.pdf.

Chou, Y-K. (2016). Actionable Gamification: Beyond points, badges and Leaderboards. London: Leanpub. 
Cruz, M. (2018). "Chicos, sacad el móvil de vuestras mochilas porque lo vamos a usar": empowering SFL students through mobile devices. The Turkish Online Journal of Educational Technology, Special Issue for INTE-ITICAM-IDEC 2018, 282-292.

Cruz, M. (2019). Por uma Didática da Gamificação para o desenvolvimento de "creactical skills" na aula de Língua Estrangeira. Paper presented at the II Jornada Internacional "Princípios e práticas de formação em línguas estrangeiras", Universidade do Minho. https://www.icloud.com/keynote/OCZ AwIEWD_9PImVGOpkfQhUGA.

Cruz, M., \& Orange, E. (2016). 21st Century Skills in the Teaching of Foreign Languages at Primary and Secondary Schools. Turkish Online Journal of Educational Technology, Special Issue for IETC, ITEC, IDEC, ITICAM 2016, 1-12.

Cruz, M., \& Saracho, M. (2018). La variación diatópica del español de América a través de una (hiper) pedagogía plurilingüística e intercultural. Revista Diacrítica, Número especial dedicado al VII Congreso sobre la enseñanza del Español Lengua Extranjera en Portugal, 133-153.

Foncubierta, J., \& Rodríguez, C. (2015). Didáctica de la gamificación en la clase de español. Programa de Desarrollo Profesional. Retrieved from https://espanolparainmigrantes.files.wordpress. com/2016/04/didactica_gamificacion_ele.pdf

Guigon, G. H., J.; Vermeulen, M. (2018). A Model to Design Learning Escape Games: SEGAM. Paper presented at the 10th International Conference on Computer Supported Education, Funchal.

Kapp, K. (2012). The Gamification of Learning and Instruction: Game-based Methods and Strategies for Training and Education. San Francisco, CA: Wiley.

Nicholson, S. (2015). Peeking behind the locked door: A survey of escape room facilities. Retrieved from http://scottnicholson.com/pubs/erfacwhite.pdf.

Nicholson, S. (2016). The State of Escape: Escape Room Design and Facilities. Paper presented at the Meaningful Play 2016, Lansing, Michigan. http://scottnicholson.com/pubs/stateofescape.pdf.

Ohler, J. (2013). Digital Storytelling in the Classroom. New Media Pathways to Literacy, Learning and Creativity. London: SAGE Publications.

P21. (2015). P21 Framework Definitions. Retrieved from http://www.p21.org/storage/documents/docs/ P21_Framework_Definitions_New_Logo_2015.pdf.

Werbach, K., \& Hunter, D. (2012). For the Win: How Game Thinking Can Revolutionize Your Business. Philadelphia: Wharton Digital Press.

Mário Rui Domingues Ferreira da Cruz $(\mathrm{PhD})$ is Associate Professor of the School of Education at Porto Polytechnic, where he teaches Spanish as a Foreign. He holds a PhD in Didactics (University of Aveiro) and a PhD in Hispanic Linguistic Studies (University of Vigo). Porto Polytechnic - School of Education / inED Centre of Research and Innovation in Education Email: mariocruz@ese.ipp.pt ORCID: https://orcid.org/0000-0001-8894-8821 
Correspondência Mário Rui Domingues Ferreira da Cruz Instituto Politécnico do Porto

Rua Dr. Roberto Frias, 712 4200-465

Porto-Portugal

Data de submissão: Setembro 2019

Data de avaliação: Outubro 2019

Data de publicação: Dezembro 2019 